\title{
The Image as Part of the Culture and Identity of a Destination. Destination Branding and Destination Image
}

\author{
Noelia Araújo* and Lucília Cardoso \\ Business and Tourism Faculty, University of Vigo, Spain
}

Submission: September 28, 2018; Published: October 12, 2018

*Corresponding author: Noelia Araújo, Business and Tourism Faculty, 32004, Ourense, University of Vigo, Spain, Email: naraujo@uvigo.es

\begin{abstract}
The image of a destination goes beyond what it has, tangible and intangible resources, reflects its identity. Forming this image is a complex process, since it depends on several factors. The tourists combine in their minds a series of variables (cognitive, affective and conative) that give rise to the image of a destination. That is why it varies from one tourist to another. The previous perceptions, the own visit to the destination and the information received from family and friends are forming the image of the destination. But this image will positively or negatively influence the re-visit to the destination and the information transmitted to other tourists. Therefore, this is a growing field of study, in which we try to have more information about this complex process.
\end{abstract}

Keywords: Image; Destination branding; Destination image; Destination; Tourism

\section{Introduction}

Nowadays, destinations seek to be known globally, being the key projected image in this process. The image of the destination reflects not only the resources it possesses, but the very identity of the destination. Cognitive and affective evaluations form the global image of a place [1]. It is therefore necessary to understand concepts such as Tourism Destination Image (TDI), since the image is an essential component in the identity of the destination [2]. There are several definitions of this concept, including some of them:

a. The sum of beliefs, ideas and impressions that a person has of a destiny [3]. b. A mental picture formed by a set of attributes that define the destination in its various dimensions [4].

c. A set of impressions about a place where tourists do not reside [5].

These three definitions cover a very long-time period, from the end of the 70s to the current decade. But all of them are based on the same idea, the mental representation that the tourist makes of a destination, whether it is the result of his impressions, experiences, ideas, beliefs or the attributes of destiny. The most recent theories group a series of factors whose union arises that mental representation (Figure 1).

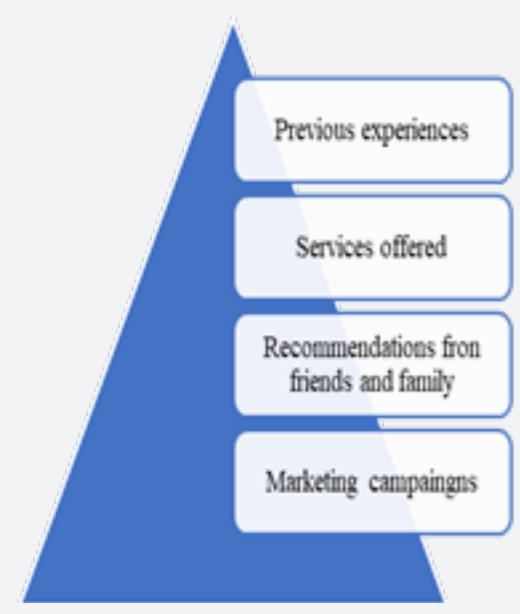

Figure 1: Factors that make up the TDI. Source: Dias and Cardoso [5]. 


\section{Global Journal of Archaeology \& Anthropology}

In addition, we can affirm that the concept of TDI is multidimensional but there is no consensus regarding its dimensions. One of the proposals is the one that adds these three dimensions: 1) image or tourist landscape of the tourist destination; 2) projected image of the tourist destination or marketing campaigns; 3) perceived image of the tourist destination or the effects of marketing and the experience in the destination on the tourist. From all this we can conclude that the concept of destination image is not totally defined, since there is no consensus in the definition of the destination's image, as well as its dimensions, the evaluation and measurement methods, the training process and of the process "before, during and after" the trip. Other authors claim that there is a lack of a main and definitive concept about the image and that the great diversity of existing concepts generates "confusion" within the literature on this subject. There are as many definitions as authors interested in defining it. What is evident is the link between image and tourist destination, or in other words, the importance of the image when choosing a tourist destination. Therefore, its study has begun to receive more attention. The image is linked to satisfaction and the intention to revisit the destination, which is why it has been studied by several researchers who have created a theoretical base and conceptual models to characterize it [6]. The image assumes an important role to consider developing marketing strategies.

\section{Destination Branding and Destination image}

The tourist destinations, to become more competitive, are betting on the concept of destination brand building. In this way, the importance of addressing issues such as destination branding, destination image and brand image arises, since the image of the destination arises as an integral component of the brand and the competitiveness of the tourism industry itself that requires a marketing plan. Thus, branding is fundamental as part of the impact on the positioning of the destination [7]. Destination branding is a concept used in marketing to refer to the intangible value or reputation of a destination through multiple dimensions of it, such as its culture, its spots, companies, organizations, tourism, etc. [8]. The original idea is of Simon Anholt, who introduced the country brand in the first instance, arising subsequent derivations as the city brand or in this case, the destination brand. Just as with the marketing of products and services, the destination brand finds its place within a strategy that seeks to highlight the competitive advantages of an entity, differentiating it from the rest of the world, to strengthen it as a magnet for tourism, investments and opportunities. Not every geographical point can be named like that, since the destination brand only exists to the extent that the public perceives it.

A target brand is not a logo, a website or a campaign; it is the result of the perceptions of its visitors and inhabitants, added the personality and attractive differentials of the place. Thus, a true destination brand has competitive advantages that are not replicable by any other in the world. As an example, we can move to Mexico, where Riviera Maya has become a tourist reference. The Mayan Riviera, as a tourist entity, was created in 1999, and today is one of the most important destinations in Mexico with a large international influx, and all this in less than 20 years. In its promotional video of 2012 it emphasizes its culture, history, location, nature, population and tourist places together activities. It is a tourist destination with a great combination of varied resources, with its promotional slogan "Paradise is forever" (Figures 2 \& 3).

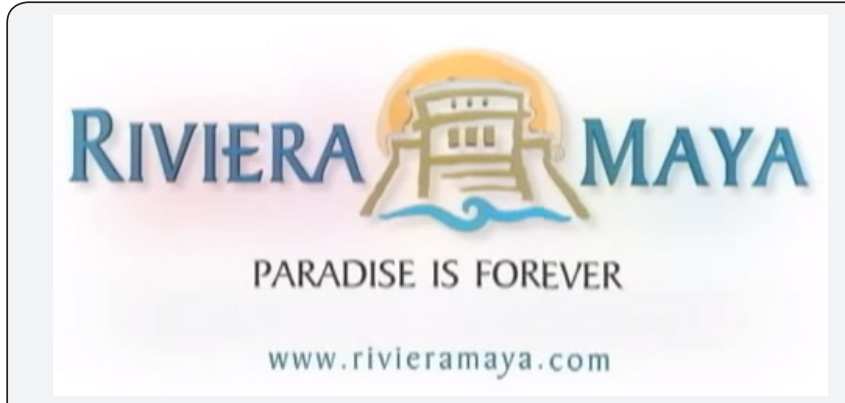

Figure 2: Riviera Maya promotion campaign 2012.
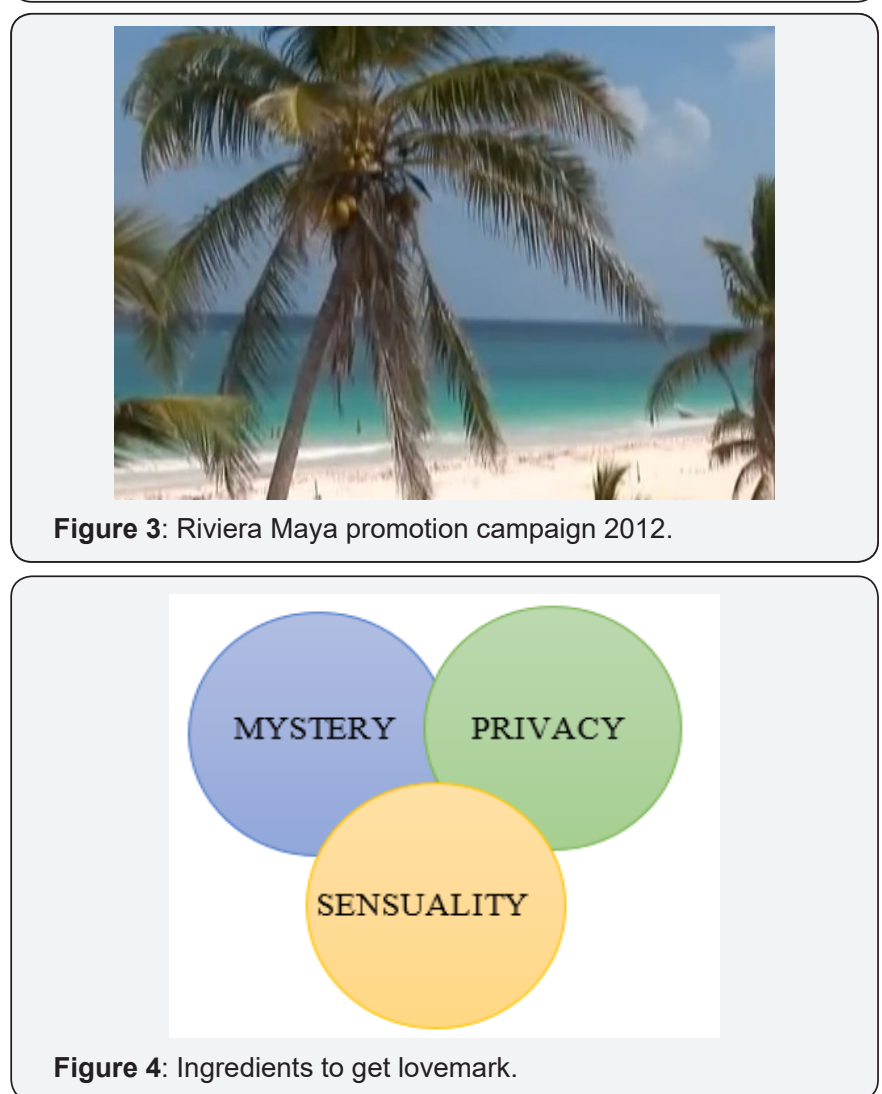

We wonder, therefore, how it has managed to be a successful brand in such a short time or how it has managed to position itself worldwide. In 2004, Kevin Roberts published the book Lovemarks, which defined these brands as those to which we are faithful beyond reason due to the emotional bond we create with them. For such a brand to exist, Roberts claimed that three ingredients should be given (Figure 4).

\section{Mystery}

There must be a story to tell, a past, but with the ability to project into the future; there must be dreams, myths, symbols, metaphors. An example of this is the Life and Death Festival in 


\section{Global Journal of Archaeology \& Anthropology}

Xcaret, an event that in just four days receives more than 40 thousand people eager to live something that only Mexico has been offering for centuries: the personal encounter with death to remember those who have gone and live with them for one night.
Tourists of all nationalities flood the park, painting the faces of skulls to witness stories, traditions and shows that revolve around the grim reaper and its mystery (Figure 5).

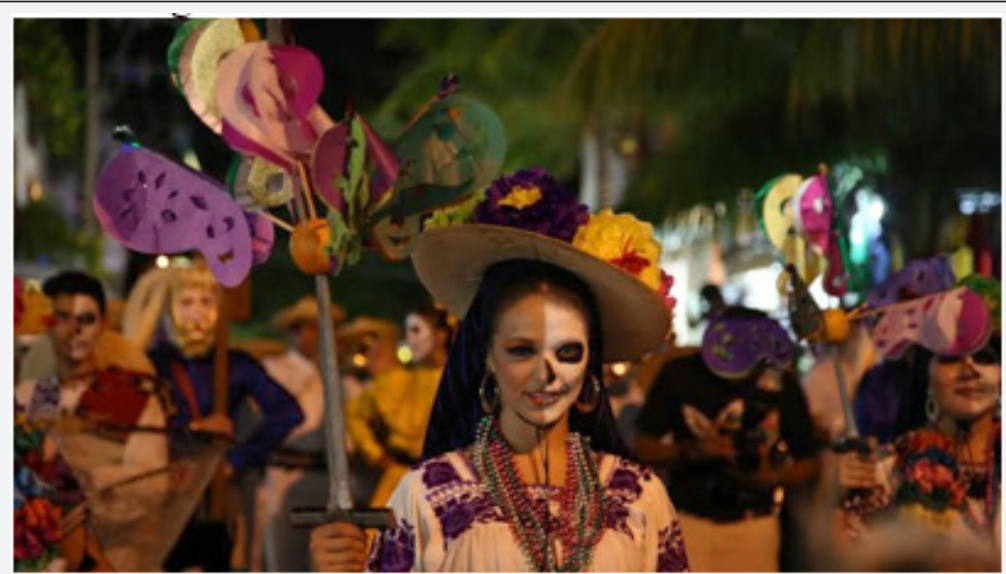

Figure 5: Life and Death Festival in Xcaret.

\section{Privacy}

In these brands, commitment, empathy and passion are perceived. Returning to the case of La Riviera Maya, unlike any traditional marketing product, it does not have a specific audience, it has a heart capable of beating for everyone, regardless of race, sex, nationality or preferences. The Riviera Maya breaks paradigms of segmentation; it is a paradise with which anyone could feel identified; all are welcome to meet from the cosmopolitan $5^{\text {th }}$ avenue in Playa del Carmen to the thematic hotels like the Hard Rock or luxurious like the Grand Velas.

\section{Sensuality}

Figure 6: Glastonbury Festival (UK) and FIB (Spain)
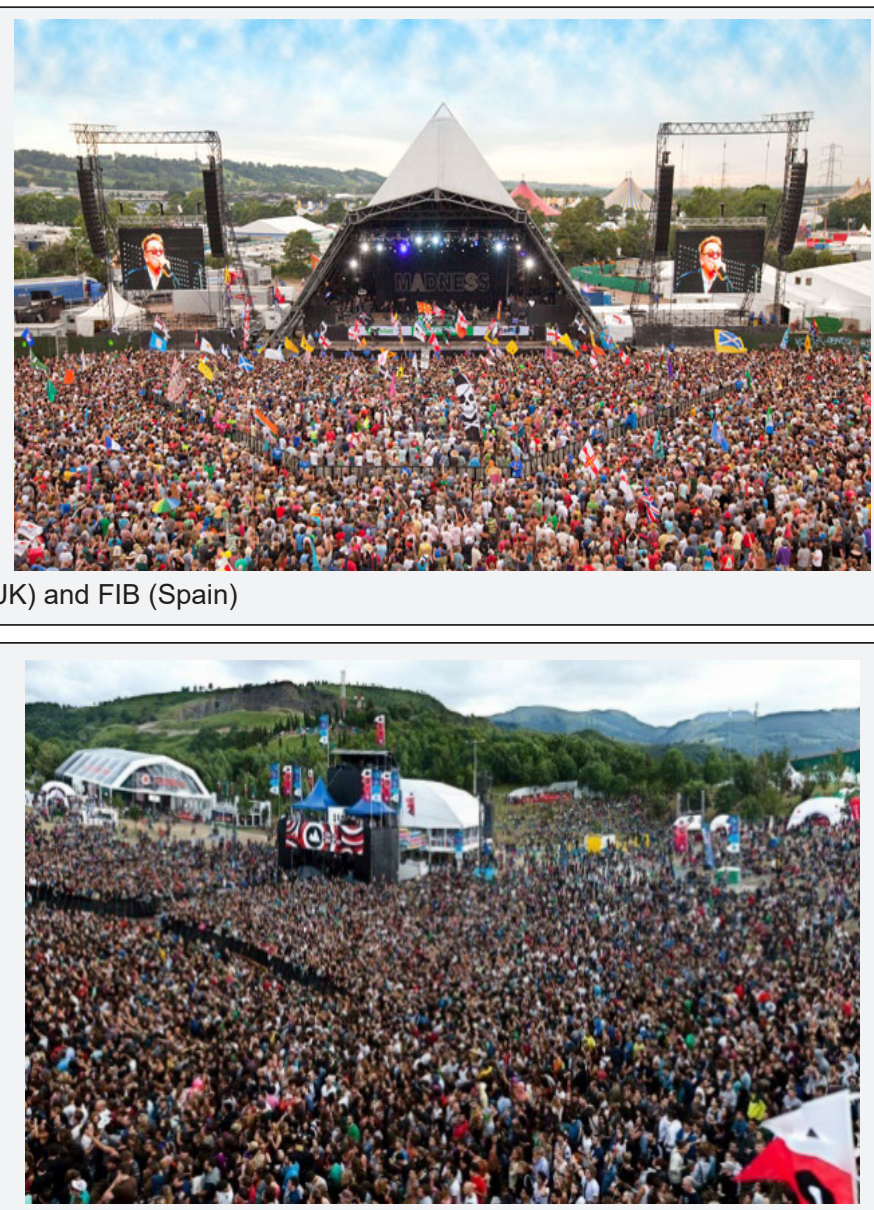

Figure 7: Glastonbury Festival (UK) and FIB (Spain). 


\section{Global Journal of Archaeology \& Anthropology}

The brands must provoke sensations, connect with the senses: they give us sounds, lights, smells, textures, flavors. This is common in music, film or theatre festivals. The spectator immerses himself in the spectacle and enjoys it with all the senses. Some are already well known that give renown to the place where they are held, such as Glastonbury in the UK, with more than 25 years or the FIB (International Festival of Benicàssim, Spain) with 23 editions (Figures $6 \& 7$ ).

Despite the examples given, these approaches to the branding of the tourist destination are recent in the world of tourism and interpreted and defined based on previous work and / or the result of professional research itself. The study of destination branding as a discipline for marketing researchers appeared in the late nineties, although the study of branding is more than 50 years old. In the last decades the concept of Brand has been adapted to different contexts. As Brand of countries, refer to the different campaigns and slogans of Spain and its brand Spain, which is very present in its promotional strategy. The tourist brand Spain is the reflection of the perception that all the agents that are part of its environment have on the country: real and potential tourists, private sector, media, etc., so that its good positioning is crucial to carry out the promotion of destiny successfully. That is why this is one of the most important objectives of the Tourism Institute of Spain: achieving an optimal positioning of the tourism brand in Spain, collaborating with the rest of the public bodies in charge of ensuring the rest of the dimensions of the brand. In 2002, the first project of the Spain brand was launched with the Joan Miró sun as logo and clear objective, to enhance the image of Spain in a coordinated way. This is demonstrated by the advertising campaigns of Tours pain that have taken place over these years. In addition to the legendary 'Spain is different' of the 80s, which despite the time elapsed is still linked to this country brand, since 2002 other slogans such as 'España Marca' ('Spain Marks') resonate in 2003; ¡Sonríe, estás en España! ('Smile, you are in Spain! linking it to different types of tourism, Figures 8 \& 9), in 2005; or 'I need Spain ', in 2010.

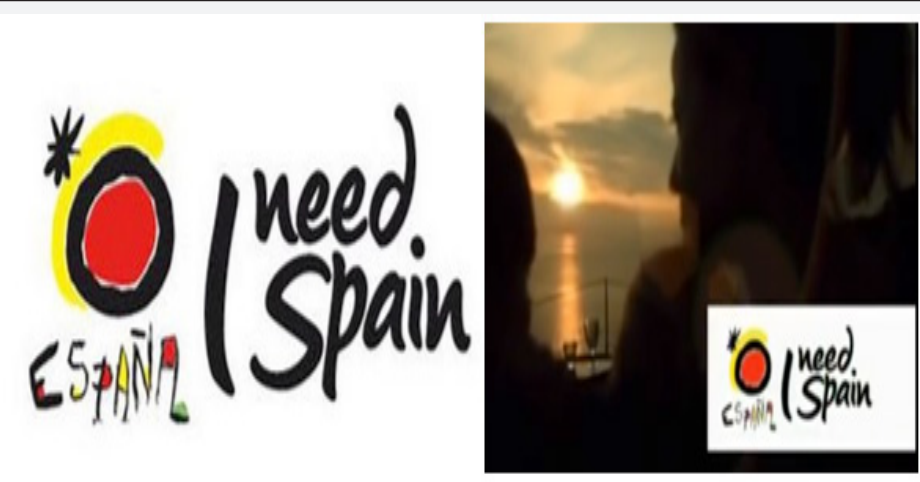

Figure 8: Spain Brand campaigns.

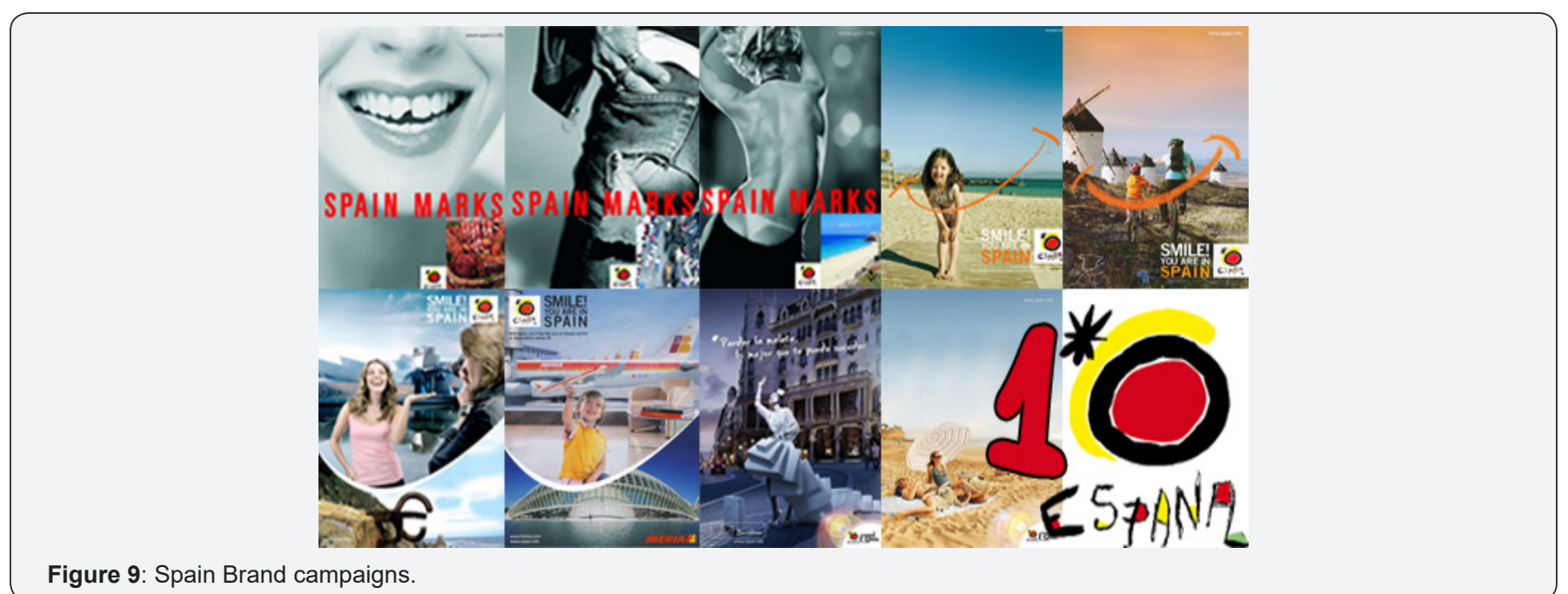

Figure 9: Spain Brand campaigns.

A brief analysis of the evolution of this concept shows that destination branding has evolved accompanied by other related concepts. Mainly from the term place promotion, which groups a set of techniques for the promotion of the territory abroad. This concept has given rise to the notion of place marketing, which brings together the strategies of development and planning of the territory. Subsequently, the concept of place branding arises, which groups the values and attributes of the territories, accompanied by promotion and communication strategies, adopting a management philosophy. With this concept very close to tourism, destination branding emerged focused on the area of tourism and tourist travel. From this form, it should be noted that the brand of the tourist destination is not the same brand as the brand of the products, the country or a brand. Destination branding has three essential components (Figure 10). 

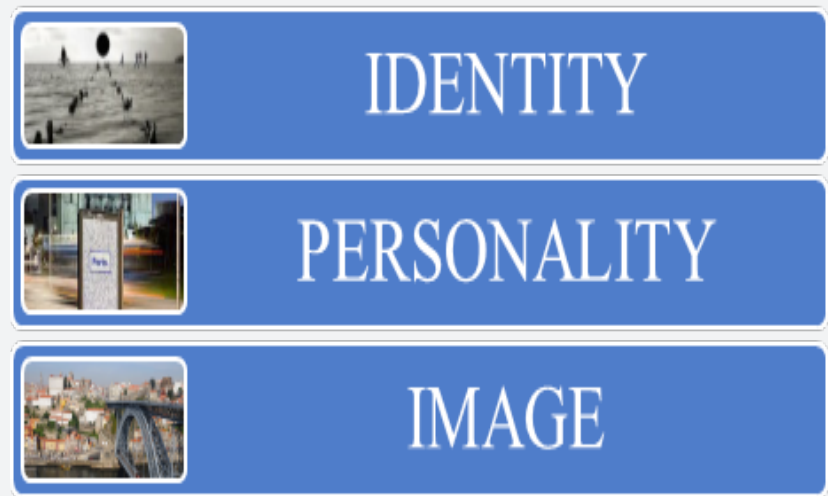

Figure 10: Destination branding components.

a. Identity of the destination: it is defined as the way in which the tourist is intended to perceive the destination.

b. Personality of destiny: the way in which destiny differs from other tourist destinations. c. Image of the destination: it appears as a fundamental component in branding, which stimulates the appearance of a set of impressions, ideas and feelings that the tourist has about the destination.

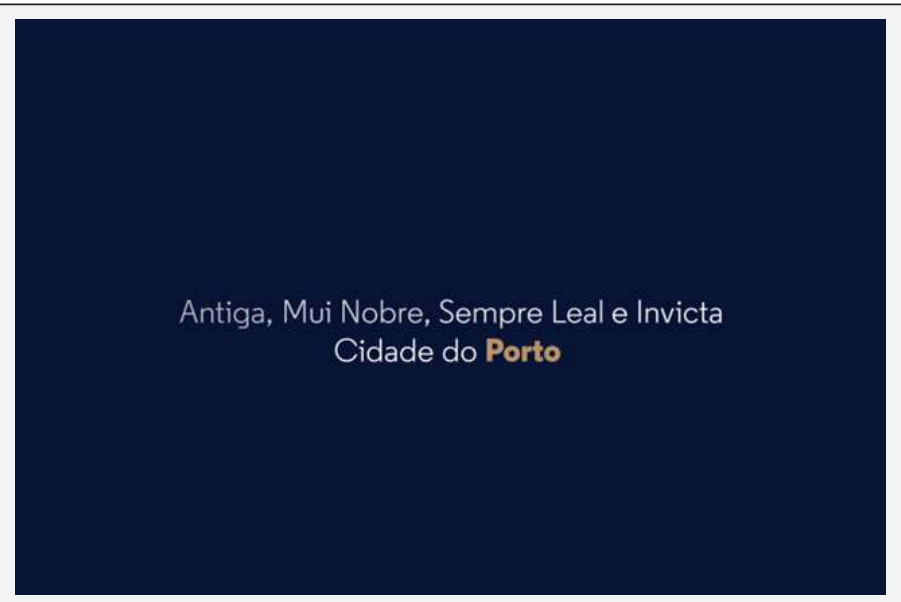

Figure 11: The new identity of Oporto (2014).

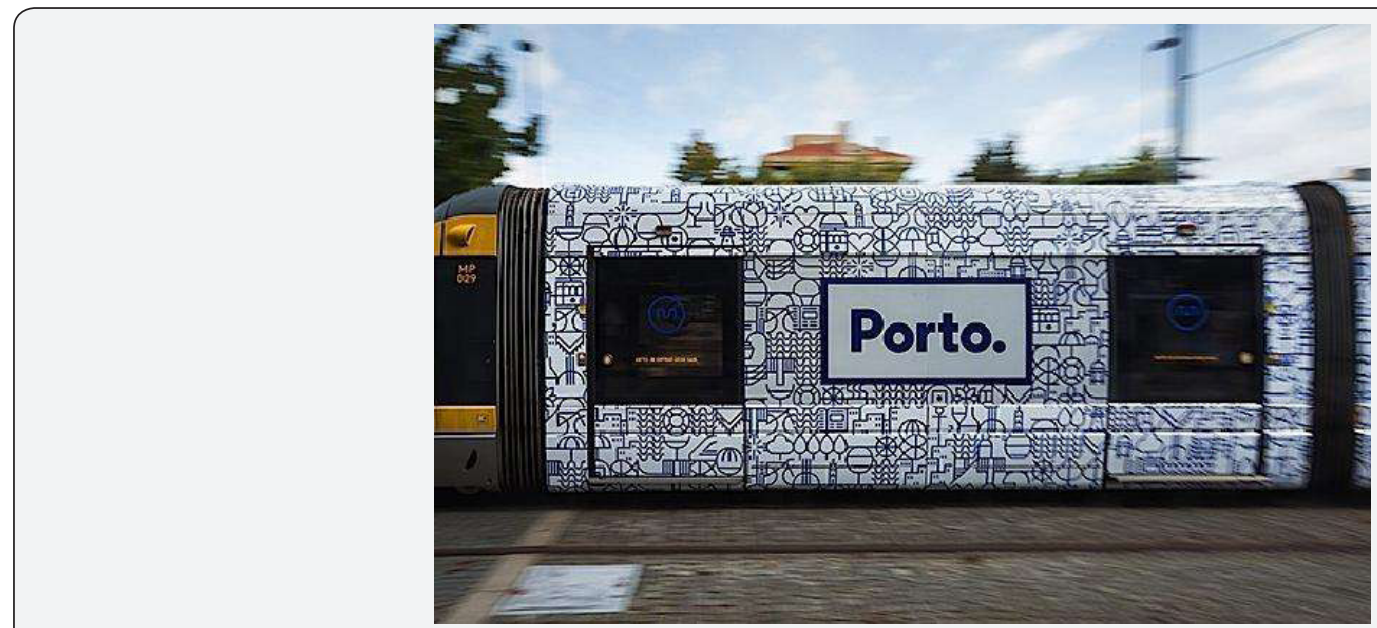

Figure 12: The new identity of Oporto (2014).

In the first component, identity, we speak of perceptions, these being an important ferment for two successive tourist destinations, a time that competitiveness between the destinations depends on how this tourist hair is perceived, mainly at the level of quality, prestige e brand image. The large number of tourist destinations and the ever-higher offer leads to increased competitiveness and the need for differentiation of destinations, which reinforces the need for branding. Up to this point there has been talk of branding and destination branding, but closely linked to this concept is that of branding image and destination image. Understanding the 


\section{Global Journal of Archaeology \& Anthropology}

image of a place allows you to recognize the place or country as a brand and consider its positive and negative aspects, that is, its strengths and weaknesses. Thus, it is essential to correctly know the Brand image of the destination so that it can be a community with clarity. An example of this was the strategy chosen by Oporto in the 2014 campaign, opting for a radical change of image. This new identity wanted to give the city a strong personality, using a clear message in the form of a simple and endless network of symbols. Oporto has a great personality that, thanks to this system or open language, can be developed in an almost unlimited way with the possibility of new communicative and touristic projects (Figures 11-14).

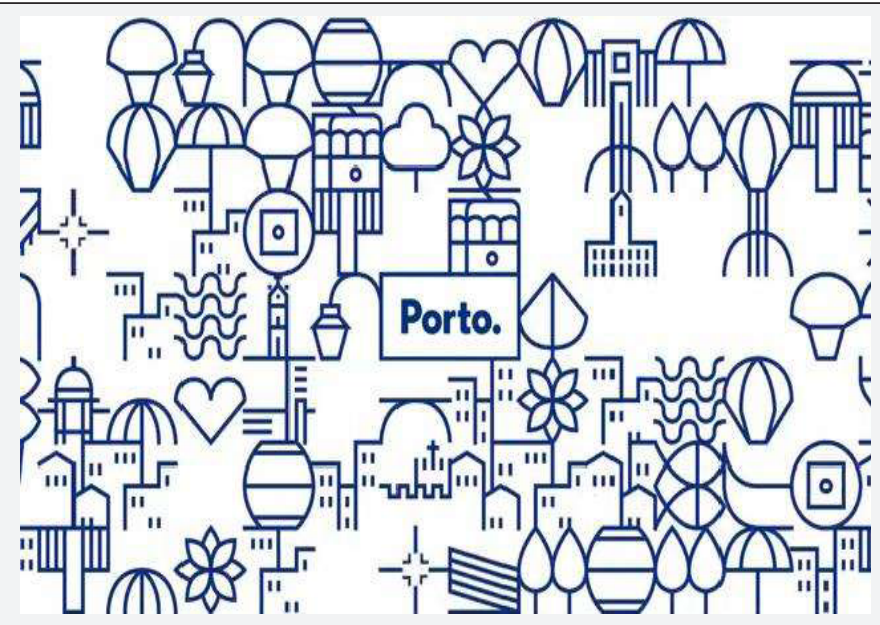

Figure 13: The new identity of Oporto (2014).

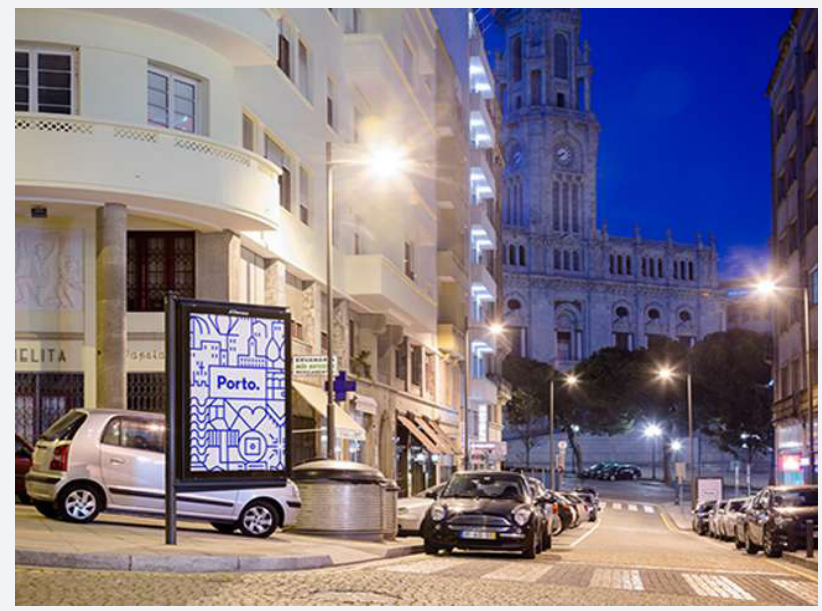

Figure 14: The new identity of Oporto (2014).

Image Components

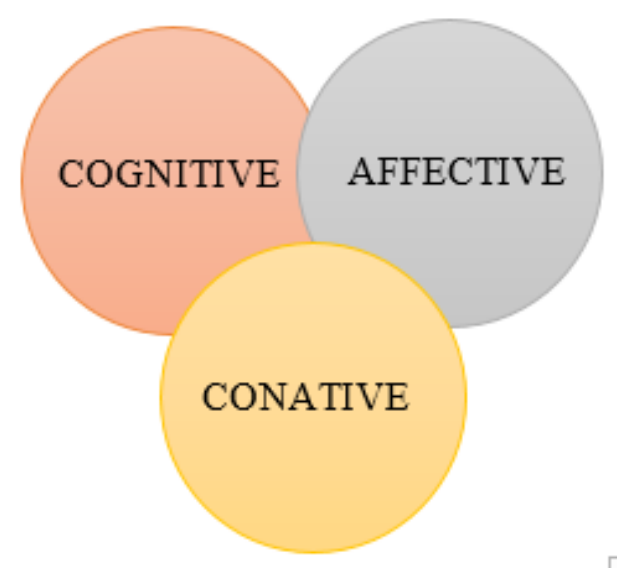

Figure 15: Image components. 


\section{Global Journal of Archaeology \& Anthropology}

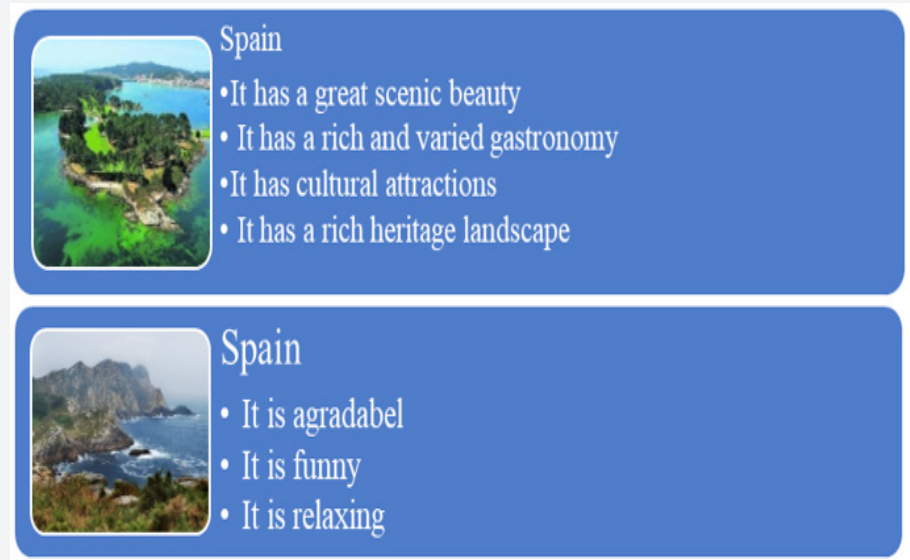

Figure 16: The image of a tourist destination is part of its identity.

Just as it is fundamentally to understand their formation, it is crucial to understand the components of the image. The image of the tourist destination is formed by three different components [9], but hierarchically related (Figure 15). The cognitive component, also called "perceptual" or "intellectual", is the result of the image and attributes of the tourist destination that has the capacity to attract tourists (Figure 16). It is a dimension of interpretation of the characteristics of the destination that includes the information that contributes to the knowledge about the destination, or in summary, it is what the individual thinks or thinks he knows about the destination.

The affective component is the result of the reason for the tourist's choice of a certain tourist destination, based on the result of his affective evaluation of it. It encompasses emotions and feelings related to the destination and is crucial in the development of the tourist with the destination and in the creation of loyalty. Concerning the conative, behavioral or behavioral intention component, this includes the way of choosing the destination based on the cognitive and affective elements that the tourist has about the destination. Based on a subjective perception of the destination, it is defined as the "action component". It expresses the behavioral side and presents a direct relationship with the cognitive and affective components, since it depends on the image developed during the cognitive stage and the evaluation made in the affective stage.

\section{Conclusion}

The image of a tourist destination is part of its identity, transmitting beyond its residents an idea of it. The tourists who do not know a place, are previously formed images of the same, based on perceptions and previous information received. This preconceived image will be the one that influences the decision to visit the destination, so transmitting a real and attractive image is key as an attractive element of the destination. Once the destination is visited, to this idea the real experiences and experiences are added, forming in the mind of the tourist a new image of the destination. This new conception will directly influence the visit of this tourist, and indirectly in new tourists, since the image formed will be transmitted to other individuals. The process of formation of the tourist image is complex, since several components (cognitive, affective and conative) are united. It is often unpredictable, but its study is important as an element of transmission of the identity of a destination and as an influential variable in the behavior of the tourist or traveler.

\section{References}

1. Baloglu S, Mc Cleary KW (1999) A model of destination image formation. Annals of tourism research 26(4): 868-897.

2. Hallmann K, Zehrer A, Müller S (2015) Perceived destination image: An image model for a winter sports destination and its effect on intention to revisit. Journal of Travel Research 54(1): 94-106.

3. Crompton JL (1979) An Assessment of the Image of Mexico as a Vacation Destination and the Influence of Geographical Location Upon That Image. Journal of Travel Research 17(4): 18-23.

4. Beerli A, Martín JD (2004) Factors Influencing Destination Image. Annals of Tourism Research 31(3): 657-681.

5. Dias F, Cardoso L (2017) How can brand equity for tourism destinations be used to preview tourists destination choice? An overview from the top of Tower of Babel. Tourism \& Management Studies 13(2): 13-23.

6. Echtner C \& Ritchie J (1993) The measurement of destination image: An empirical assessment. Journal of Travel Research 31(4): 3-13.

7. Campelo A, Aitken R, Thyne M, Gnoth J (2014) Sense of place: The importance for destination branding. Journal of Travel Research 53(2): 154-166.

8. Kladou S Kavaratzis M Rigopoulou I \& Salonika E (2016) The role of brand elements in destination branding. Journal of Destination Marketing \& Management 6(4): 426-435.

9. Moraga ET, Artigas EAM, Irigoyen CC (2012) Desarrollo y propuesta de una escala para medir la imagen de los destinos turísticos (IMATUR). Revista Brasileira de Gestão de Negócios 14(45): 400-418. 
This work is licensed under Creative Commons Attribution 4.0 License BY DOI: 10.19080/GJAA.2018.07.555702
Your next submission with Juniper Publishers will reach you the below assets

- Quality Editorial service

- Swift Peer Review

- Reprints availability

- E-prints Service

- Manuscript Podcast for convenient understanding

- Global attainment for your research

- Manuscript accessibility in different formats ( Pdf, E-pub, Full Text, Audio)

- Unceasing customer service

Track the below URL for one-step submission https://juniperpublishers.com/online-submission.php 